UDC 633.15:[632.7:632.935.1

633.15:631.563

Original research paper

doi: 10.5937/AASer1948143G

Acta Agriculturae Serbica, Vol. XXIV, 48(2019); 143-155

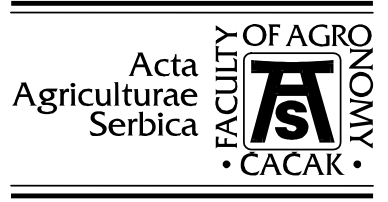

\title{
Low temperature tolerance of Plodia interpunctella, Sitophilus oryzae and Sitophilus zeamais - the prevalent pests of stored maize in Serbia
}

\author{
Sonja Gvozdenac ${ }^{1}$, Snežana Tanasković ${ }^{2}$, Jelena Ovuka1, Filip Vukajlović ${ }^{3}$, \\ Petar Čanak ${ }^{1}$, Dejan Prvulović ${ }^{4}$, Aleksandar Sedlar ${ }^{4}$ \\ ${ }^{1}$ Institute of Field and Vegetable Crops, Novi Sad, Serbia \\ ${ }^{2}$ University of Kragujevac, Faculty of Agronomy, Čačak, Serbia \\ ${ }^{3}$ University of Kragujevac, Faculty of Science, Kragujevac, Serbia \\ ${ }^{4}$ University of Novi Sad, Faculty of Agriculture, Novi Sad, Serbia \\ Corresponding author: sonja.gvozdenac@ifvens.ns.ac.rs
}

\begin{abstract}
Insect's bionomics and development are highly dependent on the environmental temperature. For centuries, this fact has been used for the control of storage pests. However, the temperature threshold depends on the species, life stage, acclimation and exposure period. This work assessed the effects of low temperatures $\left(4,-4,-10,-15\right.$ and $\left.-18^{\circ} \mathrm{C}\right)$ and exposure period $(10,30,60,120$ and $180 \mathrm{~min})$ on the survival and development of Plodia interpunctella larvae, and adults of Sitophilus oryzae and S. zeamais, the prevalent maize pests in Serbia. Data were analysed using one-way and two-way ANOVA. Additionally, Probyt analysis was performed to determine the $\mathrm{LT}_{50}$ and $\mathrm{LT}_{99}$. The first significant effects were recorded at $-4{ }^{\circ} \mathrm{C}$ for $S$. oryzae when the mortality was $41 \%$ after 120 and $52 \%$ after $180 \mathrm{~min}$ of exposure. At $-10^{\circ} \mathrm{C}$, the mortality of $S$. zeamais was significant after $180 \mathrm{~min}(52.5 \%)$ and increased with the exposure period. The significant mortality of $P$. interpunctella larvae was at $-15^{\circ} \mathrm{C}$ after $10 \min (55.5 \%)$. At $-18^{\circ} \mathrm{C}, P$. interpunctella larvae were the most susceptible and $98 \%$ of mortality was recorded after $10 \mathrm{~min}$, while $77.5 \%$ of $S$. oryzae and $68 \%$ of $S$. zeamais was recorded after $10 \mathrm{~min}$. Twoway ANOVA showed that both factors (temperature and exposure) significantly affected the mortality of tested species, but the first factor was the most influential. These results indicate that temperature and exposure period should be adjusted to specific pest, while in combined infestations the temperature should be adjusted to the most tolerant one.
\end{abstract}

Received 7 October 2019 Accepted 24 December 2019 
Keywords: Storage pests, Indian meal moth, Rice weevil, Maize weevil, cold treatment, tolerance.

\section{Introduction}

Insect pests are a major factor of post-harvest losses of stored commodities over the world. The estimates on the post-harvest losses caused by insects are variable. According to FAO (2010), losses that result from poor post-harvest management, including insect infestations, were estimated at 20-30\% and represent an important constraint to improving food security. APHLIS (2011) and Cao et al. (2002) reported the potential losses of $20-80 \%$ within a few months after harvest unless insects are controlled. Many authors emphasise that insects are prevalent pests of stored maize in Africa and Asia and can cause losses of up to $30 \%$ after six months of storage (Affognon et al., 2015; Boxall, 2002). In Serbia, maize is an important staple crop, cultivated on around 901.700-1.060.000 ha (Statistical Office of the Republic of Serbia, 2019), with stable annual production. However, in storages, maize is threatened by several pests which cause significant losses, both qualitative and quantitative. Major pests of stored maize in Serbia are Indian meal moth (Plodia interpunctella L.), rice and maize weevil (Sitophilus oryzae (L.) and Sitophilus zeamais (Motschulsky). P. interpunctella is a secondary pest that causes direct damages by feeding on germinal part of kernels (Vukajlović et al., 2017; Gvozdenac et al., 2018). Also, it causes the reduction of grain quality due to the presence of exuviae, feces, webbing, cadavers etc. The second two species are classified as the most important primary pests of stored maize, whose adults damage the whole grain. Their larvae inhabit and feed inside the kernels (Rees, 2004; Beckett et al., 2007), causing reduction of grain quantity, quality and production of a considerable amount of dust and frass. The most significant damages and losses occur in storages of high category of seeds, when both primary and secondary pests negatively affect germination, resulting in total loss of seeds value.

The control of storage pests is inevitable measure that ensures rentability and profitability of maize production. In storages, insects are mainly controlled by chemically synthetisized fumigants (phostoxine), seed treatments with insecticides (a.i. pyrimiphos methyl, deltamethrin, tefluthrin etc.), as well as by spray applications of different insecticidal products in empty storages and storages with packed goods. Due to the rising concern over the use of conventional pesticides in terms of health and environmental hazards, insect resistance and potentially restricted use of these compounds in the near future (WMO, 1994), there is a growing interest in alternative means of controlling storage pests and disinfesting food in storages (Fields, 1992). The most applied non-chemical techniques are aeration, use of diatomaceous earth or ash as seed and surface treatments, modified atmospheres and storing in insecticide-treated seed bags (De Groote et al., 2013; Tefera et al., 2011). Additionally, one of the most promising bio-rational pest management methods is the application of high and low temperatures. According to Stjeskal et al. (2019), temperature is one of the key 
environmental factors affecting the physiological, life history, behavioral and population processes of arthropods. The use of extreme, particularly low temperatures, has been extensively used to control stored-product insects due to several advantages, like no residues, efficacy against insecticide resistant strains and low risks for operators (Fields, 2001). However, there are some restraints that limit widespread adoption of this method and large-scale applications. For instance, the treatment is dependent on cold ambient air or refrigeration equipment and the duration of treatment is longer that with high temperatures, including high energy costs. The success of cold treatment depends on a number of factors such as species, developmental stage of target insect, the level of cold acclimation, temperature attained, exposure and relative humidity. Subramanyam et al. (2011) emphasised that time of exposure to high temperatures is an important factor that has to ensure the penetration of heat in cracks in floor or wall spaces and into any processing equipment in order to kill insects that may be hiding. This principle can also be applied in low temperature treatments.

Artificial cooling or freezing has been described as a mean of pest control by various authors decades ago (David et al., 1977; Evans, 1987; Hagstrum and Flinn, 1994; Dohino et al., 1999). Freezing dry stored products between $-10^{\circ} \mathrm{C}$ and $-20^{\circ} \mathrm{C}$ is an option for rapid disinfestation of high-value goods. For example, experiences from Germany show that, herb tea and spices producers have been successfully using a cooling chamber for more than 15 years to freeze all products upon reception, until a core temperature of $-18^{\circ} \mathrm{C}$ is reached. Cooling is achieved by adding liquid nitrogen and chamber temperatures can drop as low as $-90^{\circ} \mathrm{C}$. In Japan, Nakakita and Ikenaga (1997) reported that the commercial use of low temperature storage of rice has enabled the reduction of conventional fumigants since 1991. Nowadays, the method of grain preservation by cooling has been used worldwide, primarily in developed countries while in underdeveloped countries its use is not so spread, due to expensive power source and construction of storage facilities. However, there is increasing use of cooling treatment of dry grains by applying stationery or mobile devices of «Granifrigor» type in Serbia and neighbouring countries, as Salha et al. (2010) reported for Croatia.

According to Stjeskal et al. (2019), low temperatures affect both the individual and population development and all physiological and behavioral activities. It is well known that with decreasing/increasing temperature, insects' development gradually slows down, and at a certain point stops completely. Although the influence of temperatures on insect bionomics, relationship between the developmental rate and temperature as well as the minimal temperature requirements have been well elaborated by several authors (Honek and Kocourek, 1990; Kiritani, 1997; Jarosik et al., 2011) and generally it has validity for all arthropods, there are significant differences in the absolute values of specific minimum and maximum thresholds. The knowledge about pests thermal requirements, especially threshold temperatures at which development and other activities of harmful species cease (development, flying, walking, reproduction, respiration etc.), is of crucial importance for the protection of stored products and for the food industry in general (Stjeskal et al., 2019). In practice, the knowledge on the 
specific thresholds must be implemented in order to achieve efficient cooling treatments and successfully disinsect commodities.

As stated by Stjeskal et al. (2019), the research on the effects of temperature on insects has been documented since the $18^{\text {th }}$ century, providing ample scientific results that give substantial insights into the physiology, ecology distribution of certain pests as well as a background for many practical applications, such as pest monitoring and control. However, this author has identified the problem of the high variability of already existing data for identical species (referring to $P$. interpunctella in particular) which introduces uncertainty. This fact indicates the necessity of conducting studies to complete the missing data and to validate already existing but highly variable data under various conditions.

This work aimed to contribute to the above-mentioned goal, by assess the tolerance, namely the survival thresholds, of three predominant pests of stored maize $(P$. interpunctella, Sitohpilus oryzae and S. zeamais), to low temperatures depending on the exposure period.

\section{Material and methods}

\section{Insect cultures}

The most prevalent pests of maize were used in this study: Indian meal moth $(P$. interpunctella L.), rice weevil (Sitohpilus oryzae L.) and maize weevil (S. zeamais Motschulsky). Specimens of all three species originate from laboratory populations reared in the Laboratory for phytopathology at Sunflower department, Institute of Field and Vegetable Crops, Novi Sad, Serbia.

$P$. interpunctella laboratory population was reared for 10 generations on a Standard laboratory diet (SLD) for this pest (Silhachek and Miller, 1972) in an environmental growth chamber at $27 \pm 2{ }^{\circ} \mathrm{C}, 65 \%$ relative humidity $(\mathrm{RH})$, and 14:10 h L:D photoperiod, in Laboratory for phytopathology, at Institute of Field and Vegetable Crops, Novi Sad, Serbia. S. oryzae parenteral population was maintained in glass jars $(2.5 \mathrm{~L})$ on wheat kernels (variety Simonida) for one year, while $S$. zeamais was reared on dent type maize kernels (NS 640). Kernels were not treated with insecticides.

This work tested the susceptibility and tolerance levels of larval stage (mature larvae $\mathrm{L}_{4}, \mathrm{~L}_{5}$ ) of $P$. interpunctella and Sitophilus weevils to different low temperatures, at different exposure periods. Mature instars were used because they were hypothetically less vulnerable to extreme environmental conditions (Johnson et al., 2003).

\section{Experimental conditions and protocol}

Test was carried out in different laboratory freezers and refrigerators, providing desirable temperatures. In order to minimize the loss of cold air when opening the door, the freezing chamber had been sealed with a plastic sheet leaving enough space to fit in the tray with test samples and data loggers for temperature recording.

Insects were subjected to following temperatures: $4^{\circ} \mathrm{C} ;-4^{\circ} \mathrm{C} ;-10^{\circ} \mathrm{C} ;-15^{\circ} \mathrm{C}$ and $18^{\circ} \mathrm{C}$ and exposure periods: $10,30,60,120$ and $180 \mathrm{~min}$. Insects were placed in Petri 
dishes (50 specimens per dish) and exposed to each temperature, without seeds. After the given exposure period, the samples were removed from the freezer or refrigerator and transferred to a temperature-controlled chamber at $25^{\circ} \mathrm{C}$ and $65 \pm 5 \% \mathrm{RH}$ to be checked for survival two days after the exposure. Each temperature-time combination was replicated four times, while the control Petri dishes that were kept at room temperature $\left(25^{\circ} \mathrm{C}\right.$ and $65 \pm 5 \% \mathrm{RH}$.), were used to determine the natural mortality of insects.

The tolerance to low temperatures was assessed based on the mortality of test insects. The data of mortality were presented as percentage, corrected for natural mortality in untreated controls according to Abbott (1925).

\section{Statistical analyses}

Results on the mortality, after Abbott's correction, were processed with one-way ANOVA, using Bonferroni test, to test the differences between the mortality among treatments. Additionally, two-way ANOVA was used to determine the influence of two factors on the mortality of different factors (temperature, exposure) and their interaction (temperature*exposure) on mortality of $P$. interpunctella larvae, $S$. oryzae and $S$. zeamais weevils.

The exposure-mortality data of each species were subjected to Probyt analysis for estimating the time required to kill $95 \%$ and $99 \%\left(\mathrm{LT}_{50}\right.$ and $\left.\mathrm{LT}_{99}\right)$ of the exposed insects at corresponding temperature.

Statistical analysis was performed in SPSS19, software (IBM SPSS, 2017).

\section{Results}

The mortality (\%) of $P$. interpunctella larvae, S. oryzae and S. zeamais weevils after the exposure to low temperatures are presented in Table 1. The first effects of low temperatures were visible at $-4^{\circ} \mathrm{C}$, when specimens of all three species were immobile after $180 \mathrm{~min}$ of exposure. However, the mortality at this temperature was recorded only for $S$. oryzae after 60 min of exposure $(23.5 \%)$ and next two exposure periods, 120 and 180 minutes $\left(41.0\right.$, and $51.0 \%$, respectively). At $-10^{\circ} \mathrm{C}$, the highest mortality of $P$. interpunctella larvae was at the longest exposure, $180 \mathrm{~min}(36.5 \%)$. Sitophilus weevils were less tolerant to temperature of $-10^{\circ} \mathrm{C}$, so the $30 \mathrm{~min}$ exposure caused 18.0 and $19.0 \%$ mortality ( $S$. oryzae and $S$. zeamais, respectively). At longer exposure periods, it ranged from $22.5-67.0 \%$ for $S$. oryzae, and $19.0-55.2 \%$ for $S$. zeamais. The differences between mortality among different test insects, at specific exposure periods $(10,30,60,120$ and $180 \mathrm{~min})$ is highly significant $(\mathrm{F}=661.32 * *, 448.7 * *, 1408.7 * *$, $398.7 * *, \mathrm{p}<0.01$, respectively).

The highest mortality after all exposure periods was recorded for $S$. oryzae. Temperature of $-15^{\circ} \mathrm{C}$ caused high mortality of all tested species. For $P$. interpunctella larvae it ranged from $55.5 \%$ at $10 \mathrm{~min}$ exposure to $100 \%$ after 180 minutes. S. oryzae mortality was $78.0 \%$ at lowest exposure $(10 \mathrm{~min})$ up to $100 \%$ after $80 \mathrm{~min}$. S. zeamais mortality ranged from $68.0 \%$ to the total $(100 \%)$ after $180 \mathrm{~min}$. Significant difference in 
mortality between species at $-15^{\circ} \mathrm{C}$ was after 10,30 and 60 min of exposure $\left(\mathrm{F}=138.6^{*}\right.$, $154.8^{*}, 19.2^{*}, \mathrm{p}<0.05$, respectively).

Table 1. Mortality of $P$. interpunctella larvae, S. oryzae and S. zeamais weevils at different low temperatures depending on the exposure period

\begin{tabular}{|c|c|c|c|c|c|}
\hline $\operatorname{Temp}\left({ }^{\circ} \mathbf{C}\right)$ & Exposure & P. interpunctella & S. oryzae & S. zeamais & F value \\
\hline \multirow{5}{*}{4} & $10 \mathrm{~min}$ & $0 \pm 0.00 \mathrm{a}$ & $0 \pm 0.00 \mathrm{a}$ & $0 \pm 0.00 \mathrm{a}$ & $0.00 \mathrm{~ns}$ \\
\hline & $30 \mathrm{~min}$ & $0 \pm 0.00 \mathrm{a}$ & $0 \pm 0.00 \mathrm{a}$ & $0 \pm 0.00 \mathrm{a}$ & $0.00 \mathrm{~ns}$ \\
\hline & $60 \mathrm{~min}$ & $0 \pm 0.00 \mathrm{~b}$ & $2.5 \pm 0.50 \mathrm{a}$ & $0 \pm 0.00 \mathrm{~b}$ & $12.00 *$ \\
\hline & $120 \mathrm{~min}$ & $2.5 \pm 0.50 \mathrm{~b}$ & $7.0 \pm 1.00 \mathrm{a}$ & $1.5 \pm 0.50 \mathrm{~b}$ & $22.45^{*}$ \\
\hline & $180 \min$ & $7.1 \pm 1.90 \mathrm{a}$ & $6.5 \pm 1.50 \mathrm{a}$ & $0 \pm 0.00 \mathrm{~b}$ & $64.50^{*}$ \\
\hline \multirow{5}{*}{-4} & $10 \mathrm{~min}$ & $0 \pm 0.00 \mathrm{a}$ & $0 \pm 0.00 \mathrm{a}$ & $0 \pm 0.00 \mathrm{a}$ & $0.00 \mathrm{~ns}$ \\
\hline & $30 \mathrm{~min}$ & $0 \pm 0.00 \mathrm{~b}$ & $6.5 \pm 1.5 \mathrm{a}$ & $0 \pm 0.00 \mathrm{~b}$ & $108.0^{* *}$ \\
\hline & $60 \mathrm{~min}$ & $0 \pm 0.00 \mathrm{~b}$ & $23.5 \pm 4.5 \mathrm{a}$ & $0 \pm 0.00 \mathrm{~b}$ & $765.6^{* *}$ \\
\hline & $120 \mathrm{~min}$ & $1.0 \pm 0.00 \mathrm{c}$ & $41.0 \pm 3.00 \mathrm{a}$ & $25.5 \pm 4.50 \mathrm{~b}$ & $2127.9 * *$ \\
\hline & $180 \min$ & $8.50 \pm 1.5 \mathrm{c}$ & $51.0 \pm 5.00 \mathrm{a}$ & $32.5 \pm 2.50 \mathrm{~b}$ & $2765.0 * *$ \\
\hline \multirow{5}{*}{-10} & $10 \mathrm{~min}$ & $0 \pm 0.00 \mathrm{a}$ & $6.0 \pm 0.00 \mathrm{a}$ & $0 \pm 0.00 \mathrm{a}$ & $7.70^{*}$ \\
\hline & $30 \mathrm{~min}$ & $3.0 \pm 0.00 \mathrm{~b}$ & $18.0 \pm 3.00 \mathrm{a}$ & $19.0 \pm 1.00 \mathrm{a}$ & $661.32 * *$ \\
\hline & $60 \mathrm{~min}$ & $3.0 \pm 0.00 \mathrm{~b}$ & $22.5 \pm 5.50 \mathrm{ba}$ & $19.0 \pm 2.00 \mathrm{a}$ & $448.7 * *$ \\
\hline & $120 \min$ & $12.5 \pm 3.5 \mathrm{c}$ & $47.5 \pm 0.50 \mathrm{a}$ & $31.5 \pm 1.50 \mathrm{~b}$ & $1408.7 * *$ \\
\hline & $180 \mathrm{~min}$ & $36.5 \pm 4.50 \mathrm{c}$ & $67.0 \pm 3.00 \mathrm{a}$ & $52.5 \pm 3.50 \mathrm{~b}$ & $398.7 * *$ \\
\hline \multirow{5}{*}{-15} & $10 \mathrm{~min}$ & $55.5 \pm 2.50 \mathrm{c}$ & $78.0 \pm 4.00 \mathrm{a}$ & $60.0 \pm 2.00 \mathrm{~b}$ & $138.6^{*}$ \\
\hline & $30 \mathrm{~min}$ & $77.5 \pm 3.50 \mathrm{~b}$ & $82.0 \pm 4.00 \mathrm{a}$ & $76.5 \pm 2.50 \mathrm{~b}$ & $154.8^{*}$ \\
\hline & $60 \mathrm{~min}$ & $90.0 \pm 7.00 \mathrm{a}$ & $92.0 \pm 0.00 \mathrm{a}$ & $84.0 \pm 7.00 \mathrm{~b}$ & $19.2^{*}$ \\
\hline & $120 \mathrm{~min}$ & $96.5 \pm 7.50 \mathrm{a}$ & $94.5 \pm 6.50 \mathrm{a}$ & $93.0 \pm 2.00 \mathrm{a}$ & $2.22 \mathrm{~ns}$ \\
\hline & $180 \mathrm{~min}$ & $100 \pm 0.00 \mathrm{a}$ & $100 \pm 0.00 \mathrm{a}$ & $100 \pm 0.00 \mathrm{a}$ & $0.00 \mathrm{~ns}$ \\
\hline \multirow{5}{*}{-18} & $10 \mathrm{~min}$ & $98.0 \pm 0.00 \mathrm{a}$ & $77.5 \pm 8.50 \mathrm{~b}$ & $68.0 \pm 3.00 \mathrm{~b}$ & $351.9 * *$ \\
\hline & $30 \mathrm{~min}$ & $100 \pm 0.00 \mathrm{a}$ & $88.5 \pm 5.50 \mathrm{~b}$ & $81.0 \pm 5.00 \mathrm{~b}$ & $659.1 * *$ \\
\hline & $60 \mathrm{~min}$ & $100 \pm 0.00 \mathrm{a}$ & $100 \pm 0.00 \mathrm{a}$ & $100 \pm 0.00 \mathrm{a}$ & $0.00 \mathrm{~ns}$ \\
\hline & $120 \mathrm{~min}$ & $100 \pm 0.00 \mathrm{a}$ & $100 \pm 0.00 \mathrm{a}$ & $100 \pm 0.00 \mathrm{a}$ & $0.00 \mathrm{~ns}$ \\
\hline & $180 \mathrm{~min}$ & $100 \pm 0.00 \mathrm{a}$ & $100 \pm 0.00 \mathrm{a}$ & $100 \pm 0.00 \mathrm{a}$ & $0.00 \mathrm{~ns}$ \\
\hline
\end{tabular}


At $-18^{\circ} \mathrm{C}$, larvae of $P$. interpunctella were the least tolerant, hence the mortality was $98.0 \%$ after the shortest exposure (10 min) and $100 \%$ after $30 \mathrm{~min}$ and longer exposure. Mortality of $S$. oryzae was $77.5 \%$ after $10 \mathrm{~min}$ and $88.5 \%$ after $30 \mathrm{~min}$. S. zeamais was the most tolerant to low temperatures. At $-18^{\circ} \mathrm{C}$, after 10 min the mortality was $60.0 \%$, and $81.0 \%$ after $30 \mathrm{~min}$. The differences between the mortality of three species was highly significant only after the first two exposure periods, 10 and $30 \mathrm{~min}\left(\mathrm{~F}=351.9^{* *}\right.$, $659.1 * *, \mathrm{p}<0.05$, respectively).

The Probyt analysis (Table 2) determined the lethal period needed to achieve 50 and $99 \%$ of mortality $\left(\mathrm{LT}_{50}\right.$ and $\left.\mathrm{LT}_{99}\right)$ of $P$. interpunctella larvae, $S$. oryzae and $S$. zeamais weevils at each applied temperature. As presented, the shortest period at $4^{\circ} \mathrm{C}$ since the mortality was too low, the Probyt calculation was not relevant, therefore was not put in the Table. In other temperature treatments, it took the shortest time, at each temperature to kill $50 \%$ of $S$. oryzae population compared to other two species, while at $-18^{\circ} \mathrm{C}$, the time need to achieve the mortality of $50 \%$ of $P$. interpunctella was 1.9 min and for $S$. zeamais $(2.2 \mathrm{~min}$ ) did not differ significantly. Lethal time for $99 \%$ mortality depended on the temperature (Table 2).

Table 2. $\mathrm{LT}_{50}$ and $\mathrm{LT}_{99}$ at different temperatures for P. interpunctella larvae, S. oryzae and $S$. zeamais weevils

\begin{tabular}{l|l|c|c|c|c|c}
\hline \multirow{2}{*}{ Insect species } & \multirow{6}{*}{} & \multicolumn{5}{|c}{ Temperature } \\
\cline { 3 - 7 } & & $\mathbf{4}^{\circ} \mathbf{C}^{*}$ & $\mathbf{- 4}{ }^{\circ} \mathbf{C}$ & $\mathbf{- 1 0}{ }^{\circ} \mathbf{C}$ & $\mathbf{- 1 5}{ }^{\circ} \mathbf{C}$ & $\mathbf{- 1 8}{ }^{\circ} \mathbf{C}$ \\
\hline \multirow{2}{*}{ P. interpunctella } & LT50 & $\mathrm{x}$ & 542.1 & 296.3 & 9.2 & $\mathbf{1 . 9}$ \\
& $\mathbf{L T 9 9}$ & $\mathrm{x}$ & 978.6 & 306.0 & 190.50 & 12.80 \\
\hline \multirow{2}{*}{ S. oryzae } & LT50 & $\mathrm{x}$ & $\mathbf{1 5 9 . 6}$ & $\mathbf{1 2 2 . 4}$ & $\mathbf{4 . 3}$ & $\mathbf{2 . 1}$ \\
& $\mathbf{L T 9 9}$ & $\mathrm{x}$ & 394.1 & 309.1 & 23.5 & 15.6 \\
\hline \multirow{2}{*}{ S. zeamais } & LT50 & $\mathrm{x}$ & 216.7 & 190.7 & 7.4 & 6.8 \\
& LT99 & $\mathrm{x}$ & 655.8 & 356.4 & 16.3 & 13.2 \\
\hline
\end{tabular}

*Due to very low mortalities $(0-7.1 \%)$ it was impossible to calculate the relevant LT values, therefore these values were omitted from the table

Two-way ANOVA determined the influence of two factors (temperature and exposure) and their interaction (temperature*exposure) on the mortality of $P$. interpunctella larvae, $S$. oryzae and $S$. zeamais weevils. The results presented in Table 3 indicate that both factors and their interaction significantly affected mortality of all three species. However, based on the values of the Sum of Squares, the most influential factor in all cases was the temperature, followed by exposure period and interaction. 
Table 3. The influence of different factors (temperature, exposure) and their interaction (temperature*exposure) on the mortality of $P$. interpunctella larvae, $S$. oryzae and $S$. zeamais weevils

\begin{tabular}{|c|c|c|c|c|}
\hline Insect species & Source & SS & df & $\mathbf{F}$ \\
\hline \multirow{4}{*}{ P. interpunctella } & Corrected Model & $144947.580^{\mathrm{a}}$ & 24 & $35.75 * *$ \\
\hline & temperature & 134531.613 & 4 & $199.089 * *$ \\
\hline & exposure & 4151.813 & 4 & $6.14 * *$ \\
\hline & temperature * exposure & 6264.153 & 16 & $2.31 *$ \\
\hline \multirow{4}{*}{ S. oryzae } & Corrected Model & $113750.880^{\mathrm{a}}$ & 24 & $8463.61 * *$ \\
\hline & temperature & 98419.680 & 4 & $43937.35 * *$ \\
\hline & exposure & 10680.780 & 4 & $4768.20 * *$ \\
\hline & temperature * exposure & 4650.420 & 16 & $519.02 * *$ \\
\hline \multirow{4}{*}{ S. zeamais } & Corrected Model & $117391.380^{\mathrm{a}}$ & 24 & $3650.23^{* *}$ \\
\hline & temperature & 104947.980 & 4 & $19579.85 * *$ \\
\hline & exposure & 8668.380 & 4 & $1617.23 * *$ \\
\hline & temperature $*$ exposure & 3775.020 & 16 & $176.07 * *$ \\
\hline
\end{tabular}

Df - degrees of freedom; SS - Type III Sum of Squares

\section{Discussion}

Back in 1934, Nagel emphasized that in order to obtain the most economical combination of the temperature and exposure for storage pest control, it is necessary to obtain actual data on the time required to kill a certain insect species at a certain low temperature. Driven by this thought, this work assessed the low temperature tolerance of three most important pests of stored maize, $P$. interpunctella larvae, $S$. oryzae and $S$. zeamais weevils, at different exposure period. The idea derives from the fact that in practise, the joint infestations are a common scenario in maize storages in Serbia, and it is difficult to choose the adequate temperature for cold treatment that could effectively reduce the population of all three species.

Typically, stored product insects are more tolerant to temperature treatments than other insects because their habitats and are less prone to sudden temperature change (Mullen and Arbogast, 1979). According to Lewthwaite et al. (1997), the amount, method and rate of temperature, exposure, acclimation and relative humidity can influence insect response application (Fields, 1992; Brokerhof and Banks, 1993). Additionally, other factors such as diet, population density, developmental stage and gender may affect temperature tolerance of individual insects (Cline, 1970; Fields, 1992). This work proved that weevils of $S$. zeamais, as thermophilic species, were the most susceptible to low temperatures, followed by $P$. interpunctella larvae. Additionally, according to Fields (1992) and Stjeskal et al. (2019), the survival of extremely low temperatures by stored product beetle pests is associated with their cold 
acclimation, the relative humidity of the air and the commodity moisture content. Extremely low temperatures (i.e., frost) are known to kill sensitive and non-acclimatized pests in hours or days. Extreme temperatures are rapidly effective but can be economically and technologically demanding. However, it was recognized that prolonged exposure to suboptimal temperatures may provide substantial levels of control within weeks or months (Beckett, 2011).

According to Fields (2001), larvae of Lepidoptera species (moths) that infest stored products can only penetrate a few centimetres into the grain, therefore are exposed to some of the most extreme temperatures in the grain bulk. Nevertheless, Lepidoptera are some of the most cold-hardy insects among storage pests. Adler (2010) reported that at $10^{\circ} \mathrm{C}, P$. interpunctella was controlled at the longest exposure time of $8 \mathrm{~h}$. Stage and cold acclimation can greatly increase the cold tolerance. Under similar conditions, Fields and Timlick (2010) found that fifth instars of $P$. interpunctella had $98 \%$ mortality after $48 \mathrm{~h}$ at $-10^{\circ} \mathrm{C}$. For cold acclimated diapausing larvae of $P$. interpunctella, after 14 days, the mortality was $88 \%$. In this work, we did not use diapausing or acclimated larvae, which made them more susceptible to low temperatures. However, the longest exposure to this temperature lasted only $180 \mathrm{~min}$ and caused mortality of $36.5 \%$, but according to Probyt analysis, it would take 306.0 min (5.1 hours) to reach $100 \%$ mortality of this pest. At $-18^{\circ} \mathrm{C}$, larvae of $P$. interpunctella were controlled after an exposure time of $30 \mathrm{~min}$ in study performed by Adler (2010), while in our study, after $10 \mathrm{~min}$ of exposure, it was $98.0 \%$, and after $30 \mathrm{~min}$, total mortality was achieved. Johnson et al. (1997) report that postharvest storing of dried fruits and nuts at low temperatures, is one of the alternatives to methyl bromide fumigation for controlling $P$. interpunctella. Long-term exposure to $10^{\circ} \mathrm{C}$ lengthened the life of adults; $50 \%$ mortality was reached after 49 days of exposure, adult mortality reached $90 \%$ after 70 days of exposure. Exposure to $10^{\circ} \mathrm{C}$ for greater than 25 days reduced egg production by more than half and reduced the number of viable eggs by nearly $90 \%$. Eggs were most susceptible to $10^{\circ} \mathrm{C}$; the exposure time estimated to obtain $95 \%$ egg mortality was 11.6 days. Based on these data it was estimated that clean product that has been under storage at $10^{\circ} \mathrm{C}$ and undisturbed for at least 4 weeks should be relatively free of this pest (Johnson et al., 1997). In our work, we assessed only the effect of much lower temperatures but on larvae of $P$. interpunctella. According to Probyt analysis it would take 1.58 days $\left(2278.1 \mathrm{~min}\right.$ ) at $4^{\circ} \mathrm{C}$ to reduce the population for $50 \%$, while to achieve $99 \%$ of mortality it would take 3.93 days (5670.0 min).

In our work, $S$. zeamais was the most tolerant species to all applied temperatures and exposure periods. Salha et al. (2010) reported that by cooling stored maize grain at $6^{\circ} \mathrm{C}$ showed different mortality of $S$. zeamais depending on exposure (days). Mean mortality value of $100 \%$ maize weevils was obtained after 43 days. According to results of mortalities from out study, the closest applied temperature was $4^{\circ} \mathrm{C}$. At this temperature, the LT values were not calculated because the mortalities were too low to obtain relevant results. However, the reduction of population at this temperature is very slow, as reported by Salha et al. (2010). 
The situation in maize storages is usually complex and involves the presence of several species at the same time. Therefore, the application of physical control measures, especially low temperatures, must be carefully conceptualized, because each species has the temperature optimum conditioned by its origin (temperate regions, continental regions etc.), evolution and ecology. Hence, the lower developmental threshold and/or lethal temperatures for one species can be sub-lethal to other species, making it more acclimatized and tolerant. Also, it must be considered that some species, like $P$. interpunctela feeds outside the kernels, while weevil species develop inside, thus the kernel provides certain physical barrier. All the mentioned indicates that the temperatures and exposure period used for the purpose of controlling insects should be adjusted to the specific pest present in storage, and in combined infestations, the temperature should be adjusted to the most tolerant one.

\section{Conclusion}

This work assessed the effect of low temperatures and exposure period on the survival and development of three prevalent maize pests in Serbia. Tested species were differently susceptible to low temperatures. Depending on the exposure period, the susceptibility is as follows: $S$. oryzae $>P$. interpunctella $>S$. zeamais. This indicates that temperatures and exposure period should be adjusted to the specific pest, while in combined infestations the temperature should be adjusted to the most tolerant one.

\section{Acknowledgment}

This work was carried out in the course of projects TR 31073, TR 31092 and OI 173038, funded by the Ministry of Education, Science and Technological Development of the Republic of Serbia.

\section{References}

Abbot W.S. (1925): A method of computing the effectiveness of an insecticide. Journal of Economic Entomology, 18: 265-267.

Adler C. (2010): Low temperature to control Plodia interpunctella and Stegobium paniceum. 10th International Working Conference on Stored Product Protection, Proceedings, JuliusKühn-Archiv, 425, 608-613.

Affognon H.C., Mutungi C., Sanginga P., Borgemeister C. (2015): Unpacking postharvest losses in sub Saharan Africa: A meta analysis. World Dev. 66: 49-68.

African Post Harvest Losses Information System (APHLIS), (2011): http://www.aphlis.net

Beckett S.J., Fields P.G., Subramanyam B. (2007): Disinfestation of stored products and associated structures using heat. In: Heat Treatments for Postharvest Pest Control (Tang J., Mitcham E., Wang S. and Lurie S., eds.), CAB International, UK,

Beckett S.J. (2011): Insect and mite control by manipulating temperature and moisture before and during chemical-free storage. Journal of Stored Products Research, 47: 284-292. 
Boxall R.A. (2002): Damage and loss caused by the larger grain borer Prostephanus truncatus. Integrated. Pest Managment Reviews, 7: 105-121.

Brokerhof A.W., Banks H.J. (1993): Cold tolerance of Tineola bisselliella (Lepidoptera: Tineidae) eggs at slow cooling rate. Journal of Stored Products Research, 29: 305-310.

Cao D., Pimentel D., Hart K. (2002): Postharvest crop losses (insects and mites). In: Pimentel, D. (ed.) Encyclopedia of pest management. CRC Press, Boca Raton, FL, USA.

Cline L.D. (1970): Indian meal moth egg hatch and subsequent larval survival after short exposures to low temperature. Journal of Economic Entomology, 63: 1081-1083.

David M.H., Mills R.B., White G.D. (1977): Effects of low temperature acclimation developmental stages stored-products insects. Environmental Entomology, 6: 181-184.

De Groote H., Kimenju S.C., Likhayo P., Kanampiu F., Tefera T., Hellin J. (2013): Effectiveness of hermetic systems in controlling maize storage pests in Kenya. Journal of Stored Products Research, 53: 27-36.

Dohino T., Masaki S., Matsuoka I., Tanno M., Takano T. (1999): Low temperature as an alternative to fumigation for disinfesting stored products. Research Bulletin of the Plant Protection Service Japan, 35: 5-14.

Evans D.E. (1987): The survival of immature grain beetles at low temperatures. Journal of Stored Products Research, 2: 79-83.

Fields P. G. (1992): The control of stored-product insects and mites with extreme temperatures. Journal of Stored Products Research, 28: 89-118.

Fields P.G. (2001): Control of Insects in Post-Harvest: Low Temperature. In: Vincent C., Panneton B., Fleurat-Lessard F. (eds) Physical Control Methods in Plant Protection. Springer, Berlin, Heidelberg.

Fields P.G., Timlick B. (2010): The effect of diapause, cold acclimation and ice-nucleating bacteria on the cold-hardiness of Plodia interpunctella. In: Carvalho O.M, Fields P.G., Adler C.S., Arthur F.H., Athanassiou C.G., Campbell, J.F., Fleurat-Lessard F., Flinn P.W., Hodges R.J., Isikber A.A., Navarro S., Noyes R.T., Riudavets J., Sinha K.K., Thorpe G.R., Timlick B.H., Trematerra P., White N.D.G. (Eds), Proceedings of the Tenth International Working Conference of Stored Product Protection, 27 June-2 July 2010, Estoril, Portugal, Julius Kühn- Archiv 425, Berlin, Germany.

Food and Agricultural Organization of the United Nations (FAO) (2010): Reducing Post-harvest Losses in Grain Supply Chains in Africa: Lessons Learned and Practical Guidelines FAO/World Bank Work. FAO Headquarters, Rome Italy (2010), pp. 18-19.

Gvozdenac S., Mitrović B. Tanasković S., Ovuka J., Vukajlović F., Tatić M., Bursić V. (2018): Suitability of Different Maize Hybrids for Development of Plodia Interpunctella (Hübner). Acta Agriculturae Serbica, 23 (45): 3-13.

Hagstrum D.W., Flinn P.W. (1994): Survival of (Coleoptera: Bostrichidae) in stored wheat under fall and winter temperature conditions. Environmental Entomology, 23: 391-395.

Honek A., Kocourek F. (1990): Temperature and development time in insects: A general relationship between thermal constants. Zoologische Jahrbücher. Abteilung für Systematik, Geographie und Biologie der Tiere, 117: 401-439.

IBM SPSS Statistics for Windows, version 19 (IBM Corp., Armonk, N.Y., USA)

Jarosik V., Honek A., Magarey R.D., Skuhrovec J. (2011): Developmental database for phenology models: Related insect and mite species have similar thermal requirements. Journal of Economic Entomology, 104: 1870-1876. 
Johnson J.A., Valero K.A., Hannel, M.M. (1997): Effect of low temperature storage on survival and reproduction of Indian meal moth (Lepidoptera: Pyralidae). Crop Protection, 16 (6): 519-523.

Lewthwaite S.E, Dentener P.R., Alexander S.M., Bennett K.V., Rogers D. J., Maindonald J.H., Connolly P.G. (1997): High Temperature and Cold Storage Treatments to Control Indian Meal Moth, Plodia interpunctella (Hübner). Journal of Stored Products Research, 34 (2-3): 141-150.

Kiritani K. (1997): The low development threshold temperature and the thermal constant in insects, mites and nematodes in Japan. Miscellaneous publication of the National Institute of Agro-Environmental Sciences, 21: 1-72.

Mullen M.A., Arbogast R.T. (1979): Time-temperature-mortality relationship for various storedproduct insect eggs and chilling times for selected commodities. Journal of Economic Entomology, 72: 476-478.

Nagel R.H. (1934): The Lethal Effect of Low Temperatures On The Various Stages Of The Confused Flour Beetle. Journal of Agricultural Research, 48:11.

Nakakita H., Ikenaga H. (1997): Action of low temperature on physiology of Sitophilus zeamais Motschulsky and Sitophilus oryzae (L.) (Coleoptera: Curculionidae) in rice storage. Journal of Stored Products Research, 33 (1): 31-38.

Rees D.P. (2004): (ed.): Insects of Stored Products. Manson Publishing, Ltd., UK.

Salha H., Kalinović I., Ivezić M., Rozman V., Liška A. (2010): Application of low temperatures for pests control in stored maize. Proceedings of the 5th International congress Flour - Bread '09, 7th Croatian congress of cereal technologists Flour - Bread '09. Ugarčić-Hardi, Žaneta (ur.). Osijek: Faculty of food technology Osijek, University of Osijek, Croatia: 608-616.

Silhacek D.L., Miller G.L., (1972): Growth and development of the Indian meal moth Plodia interpunctella (Lepidoptera: Phycitidae) under laboratory mass-rearing conditions. Annals of Entomological Society of America, 65: 1084-1087.

Statistical office of the Republic of Serbia (2019): https://data.stat.gov.rs/Home/Result/130102?languageCode=sr-Cyrl

Stejskal V., Vendl T., Li Z., Aulicky R. (2019): Minimal Thermal Requirements for Development and Activity of Stored Product and Food Industry Pests (Acari, Coleoptera, Lepidoptera, Psocoptera, Diptera and Blattodea): A Review. Insects , 10: 149.

Subramanyam Bh., Mahroof R., Brijwani M. (2011): Heat treatment of grain-processing facilities for insect management: a historical overview and recent advances. Stewart Postharvest Review, 3: 1-11.

Tefera T., Kanampiu F., De Groote H., Hellin J., Mugo S., Kimenju S., Beyene Y., Boddupualli P.M., Shiferaw B., Banziger M. (2011): The metal silo: an effective grain storage technology for reducing post-harvest insect and pathogen losses in maize while improving smallholder farmers' food security in developing countries. Crop Protection, 30: 240-245.

Vukajlović F.N., Predojević D.Z., Milošević S.D., Radulović D.R, Pešić S.B. (2017). Survival rate of Plodia interpunctella (Lepidoptera: Pyralidae) on different states of wheat and rye kernels previously infested by beetle pests. Kragujevac Journal of Science, 39: 201-208.

WMO (1994): Scientific assessment of ozone depletion. In World Meteorological Organisation global ozone research and monitoring project. report N.37. WMO, Geneva. 


\title{
OSETLJIVOST NA NISKE TEMPERATURE PLODIA INTERPUNCTELLA, SITOPHILUS ORYZAE I SITOPHILUS ZEAMAIS - DOMINANTNIH ŠTETOČINA USKLADIŠTENOG KUKURUZA U SRBIJI
}

\author{
Sonja Gvozdenac $^{1 *}$, Snežana Tanasković ${ }^{2}$, Jelena Ovuka ${ }^{1}$, Filip Vukajlović ${ }^{3}$, \\ Petar Čanak ${ }^{1}$, Dejan Prvulović ${ }^{4}$, Aleksandar Sedlar ${ }^{4}$ \\ ${ }^{1}$ Institut za ratarstvo i povrtarstvo, Maksima Gorkog 30, 21000 Novi Sad, Srbija \\ ${ }^{2}$ Univerzitet u Kragujevcu, Agronomski fakultet u Čačku, Cara Dušana 34, \\ 32000 Čačak, Srbija \\ ${ }^{3}$ Univerzitet u Kragujevcu, Prirodnomatematički fakultet, Radoja Domanovića 12, \\ 34000 Kragujevac, Srbija \\ ${ }^{4}$ Univerzitet u Novom Sadu, Poljoprivredni fakultet, Novi Sad, Trg Dositeja Obradovića \\ 8, 21000 Novi Sad, Srbija
}

\begin{abstract}
Rezime
Razviće insekata je visoko uslovljeno temperaturom životne sredine. Vekovima je ova činjenica korišćena u kontroli brojnosti skladišnih štetočina. Međutim, temperaturni pragovi zavise od vrste, životnog stadijuma, aklimatizacije i trajanja ekspozicije. U ovom radu ispitivani su uticaji niskih temperatura $\left(4,-4,-10,-15\right.$ i $\left.-18^{\circ} \mathrm{C}\right)$ i trajanja ekspozicionog perioda $(10,30,60,120$ i $180 \mathrm{~min})$ na nivo preživljavanja i razviće larvi Plodia interpunctella i imaga Sitophilus oryzae i S. zeamais, dominantnih štetočina uskladištenog kukuruza u Srbiji. Dobijeni podaci su analizirani korišćenjem one-way i two-way ANOVA. Dodatno, urađena je i Probyt analysis radi utvrđivanja $\mathrm{LT}_{50}$ i LT $_{99}$. Prvi značajni efekti niskih temperature registrovani su na $-4^{\circ} \mathrm{C}$ za imaga $S$. oryzae sa registrovanim uginućem od $41 \%$ posle 120 i $52 \%$ posle 180 min ekspozicije. $\mathrm{Na}-10^{\circ} \mathrm{C}$ uginuće imaga $S$. zeamais bilo je značajno posle ekpozicije od $180 \mathrm{~min}(52,5 \%)$ i raslo je sa trajanjem ekspozicionog perioda. Značajna smrtnost larvi $P$. interpunctella registrovana je na $-15^{\circ} \mathrm{C}$ posle $10 \mathrm{~min}(55,5 \%)$. $\mathrm{Na}-18^{\circ} \mathrm{C}$ larve $P$. interpunctella bile su osetljivije i $98 \%$ smrtnost registrovana je posle $10 \mathrm{~min}$, a u istim uslovima 77,5\% kod imaga $S$. oryzae i $68 \%$ kod $S$. zeamais. Two-way ANOVA ukazuje da oba faktora (temperatura i ekspozicija) značajno utiču na smrtnost testiranih štetočina, ali je temperatura uticajniji faktor. Dobijeni rezultati pokazuju da temperatura i ekspozicija predstavljaju manipulativne faktore koje treba prilagoditi vrsti, dok u kombinovanim infestacijama treba ih prilagoditi najtolerantnijoj štetočini.
\end{abstract}

Ključne reči: skladišne štetočine, bakrenasti plamenac brašna, pirinčani žižak, kukuruzni žižak, tretman niskim temperaturama, osetljivost. 